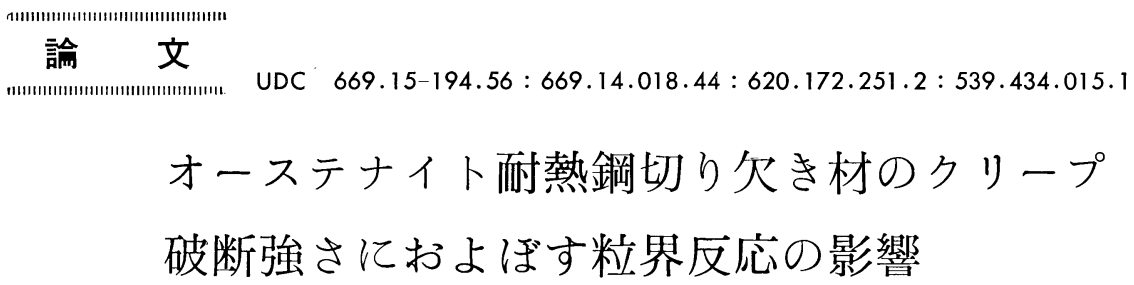

藤开 春彦*.

\title{
Effect of the Grain Boundary Reaction on the Notched Creep Rupture Strength of the Austenitic Heat Resisting Steel
}

Haruhiko FujITA, Manabu TANAKA, and Tsune-aki SAKAKI

\section{Synopsis:}

An analysis of stress and strain during creep was made on the notched bar specimens of austenitic 21-4N steel by finite element method.

A decrease in the stress concentration at notch root due to creep deformation occurred more rapidly in the notch-strengthened ductile specimen with $36 \%$ of the grain boundary reaction (GBR) than in the notchweakened brittle one of greater hardness (4\%GBR). The equivalent strain at notch root was smaller than that of smooth specimen except in the early stage of creep in the ductile steel, but the former was always larger than the latter in the strongly notch-weakened one.

In the brittle specimen, an increase in nominal stress enhanced the creep deformation at notch root and consequently lowered rupture time ratio of the notched specimen to the smooth one. Almost of the rupture life was spent in the creep deformation before the initiation of grain boundary cracks in the notched specimen as well as in the smooth specimen, independent of amount of GBR. Amount of plastic deformation necessary to initiate cracks was larger in the ductile specimen than in the brittle one. This is considered to greatly affect the rupture life of the notched specimen.

\section{1. 緒言}

オーステナイト耐熱鋼や $\mathrm{Ni}$ 基酎熱合金などの奏用合 金においては, 切り欠きの存在がクリープ破断強さへど のような影響を与えるかはとくに重要な問題のひとつで あるが，これまでに多くの研究1)〜4がなされたにもかか わらず，切り欠き強化拉よび切り欠き弱化の原因につい ては十分明らかにされていなからた。これは材料特性や 切り欠き部の形状と試験片寸法, さらには試験条件など の力学的および材料学的諸因子が相互に作用し合つて, 切り欠さ材のクリープ破断強さへ複雑な影響を拈よぼす ためと考えられる。これまでに力学的見地からは有限装 素法によつて切り欠き材のクリープ変形中の忍力拉よび ひずみの解析が行われ，応力およびひずみ分布におよぼ す試験片の幾何学的形状の影響などについて検討がなさ れてきだ)6. 。た, 従来の材料学似な研究から定性的 に，クリープ変形中の延性が十分大きい材料では切り火 き強化となる傾向にあることが知られて拈り，材料の延
性と切り欠き材のクリープ破断咄さとは业揬な威係があ る。さらに，現在の有账刑系法に上るクリーフ解析の限 界から，クリープ中の縕織変化やき裂の発牛に上るクリ ープ変形举動およびクリープ破喇特性:の変化が牛じない

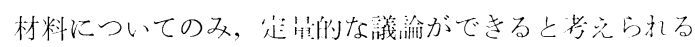
が，従来の研究ではこの点について时確にされていなか

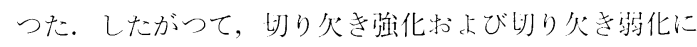

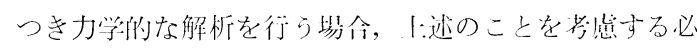
要がある.

さて，現在内然機威用排父加に沉用されているォーメ テナイト系の 21-4N 鋼では, 熱処理条件によっては通 常の粒内析出のほかに精界からバーシイト状のノジニー ルが粒界反心によつて生じるで 9). 活㴓の $600^{\circ} \mathrm{C} \sim 700$

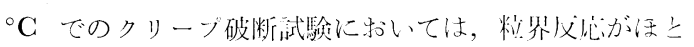
んど起こらない材料では划り火き的化となるが，約 $10 \%$ 以にの精界反応が起こつたものではとくに性料の近性が

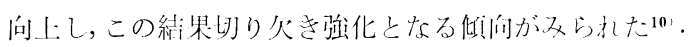

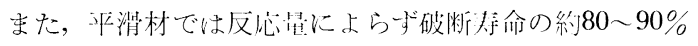

昭和 52 年 4 月本会講演大会にて一部発䇺 昭和 55 件 7 月 7 川受付 (Received July 7, 1980)

* 秋田大学鉱山学部 工博 (The Mining College, Akita University, 1-1 Tegatagakuen-cho Akita 010)

*2 東京都立大学工学部 工博 (Faculty of Technology, Tokyo Metropolitan University) 


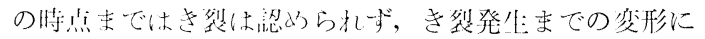

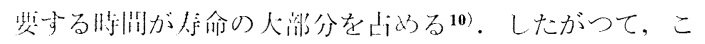
のよらな析形黛の進いが比り众材のクリープ強さに

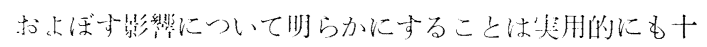

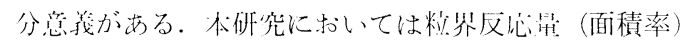
の罢なる 21-4N 鋼の沿忉および切り欠き材のクリー

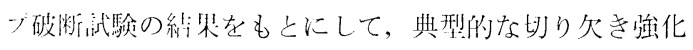
ならびに切り久き弱化を小方種颣の材料につき有限要 奖法によつて $700^{\circ} \mathrm{C}$ に拈けるクリープ変形中の切り久 き材の心括卡びひずみの解析を行い，析出形態之切り

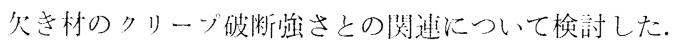

\section{2. 供試材および実験方法}

本研究では慓峾組成の $21-4 \mathrm{~N}$ 鋼 $(0.51 \% \mathrm{C}-0.40 \% \mathrm{~N}$ $-20.22 \% \mathrm{Cr}-3.90 \% \mathrm{Ni}-8.75 \% \mathrm{Mn}$-残り $\mathrm{Fe}$ ) を供試材之 して用いた。これに種々の熱処理を施し，硬さを一定

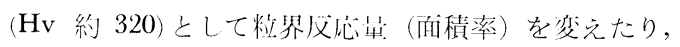
硬さを $\mathrm{Hv}$ 約 357 に战めたのり, 直徍 $7.5 \mathrm{~mm}$, 最小 断南の古柊 $5.5 \mathrm{~mm}$, 切り火き底半径 $0.5 \mathrm{~mm}\left(K_{\mathrm{t}}=\right.$ 2.4)のV型罪状切り火き付武験片および組織観祭用の二

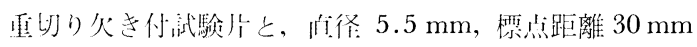

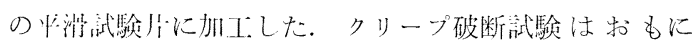

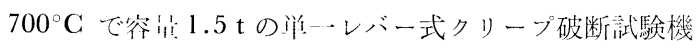
によつて行つた.さらに，クリープ破断後の北験片につ き主として光鼎によつて微視的き裂の様相を調べた。

\section{3. 有限要素法による計算の概要}

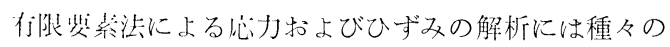
お法があるが，本研究ではクリープ変形の問題に適し， また，比較们鉒易な广法である初期ひずみ法を用いた11). 先験に用いた 21-4N 鋼は斗滑材のクリープ破断試験で

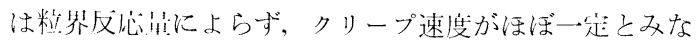
せるいわゆる造常クリープ期が長い。また，この場合定 常クリープ速度: $\dot{\varepsilon}_{\mathrm{s}}$ の芯力依存性は $\dot{\varepsilon}_{\mathrm{s}}=A \sigma^{n}$ の上らな指 数则によく命う。したがつて, 切り欠き材の場命にもミ 一ゼス形の相当伈力 $\sigma_{\mathrm{ep}}$ と相当塑性ひずみ速度 $\dot{\varepsilon}_{\text {eqp }}$ の 间に $\dot{\varepsilon}_{\mathrm{cqp}}=A \sigma_{\mathrm{eq}}^{\mathrm{n}}$ といら阅係が成立导ると仮定した。

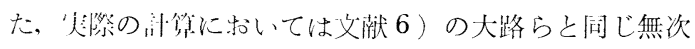
元化したクリープの式を碑いた。部算の基礎式などは文 献 6) と 11)に亦さ机ているのでここでは述べないが，

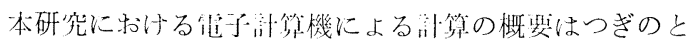
おりである。

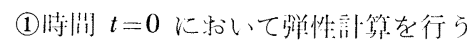

(2) $t=0$ から $t=J t$ までの間は芯力状態が変化しない ものとして, 各装䒺のクリープひずみ增分 $\left\{\Delta \varepsilon_{\mathrm{c}}\right\} を \dot{\varepsilon}_{\mathrm{eqp}}$
$=A \sigma_{\mathrm{e} q 1}^{\mathrm{n}}$ を用いて求应.

(3) $\left\{」 \varepsilon_{c}\right\}$ を初期ひずみとみなして号性汁算を行い，各 節点における荷禹增分を求和て \{\lrcorner$\left.\varepsilon_{\mathrm{e}}\right\}$ に上る各紧䒺の変 位，全ひずみおうよび忍力の增分 $\{J u\} ，\{\lrcorner \varepsilon\},\{J \sigma\}$ を 尌算する。

(4)この \{\lrcorner $u\},\{\lrcorner \varepsilon\},\{\lrcorner \sigma\}$ を任闹の㭙间に求ける备 琵素の俻に加光，新しい変位，ひずみおよび忍力の状態 を決定する。

(5)以上の(2)〜(4)までの過程をほぼ这常状態になる所分之 の時間まで繰り返す。

本研究ではクリープ変形による節点坐標の変化を考虑 して計算を行つた．Fig. 1 は本研究で用いた切り久き付 試験片の切り欠き部付近の $1 / 4$ の要素分割図で, 141 荘 索 87 節点である. 初期条件は荷重の作用与る各節点の 変位が等しくなるように共役傾斜法12)によつて荷重を求 め精度の高い弾性解を求めたのち, SOR 法13)によつて クリープ変形の各段階の計算を行つた。 なお，これらの 反復法の計算による愦差は最大約 $1 \%$ であつた，切り欠 き底の各忍力は各要素の重心の值を用い外挿によつて求 めた。 また，21-4N 鋼の $700^{\circ} \mathrm{C}$ でのヤング率 $E$ とポア ッソン比ンの值は不明なので，計算では同様のオーステ ナイト鋼である AISI 316 鋼の值 $E=14300 \mathrm{~kg} / \mathrm{mm}^{2}$, レ=0.29を用いた ${ }^{14)}$.

\section{4. 実験結果および考察}

\section{$\mathbf{4 \cdot 1}$ クリープ破断試験の結果について}

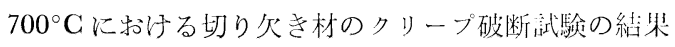

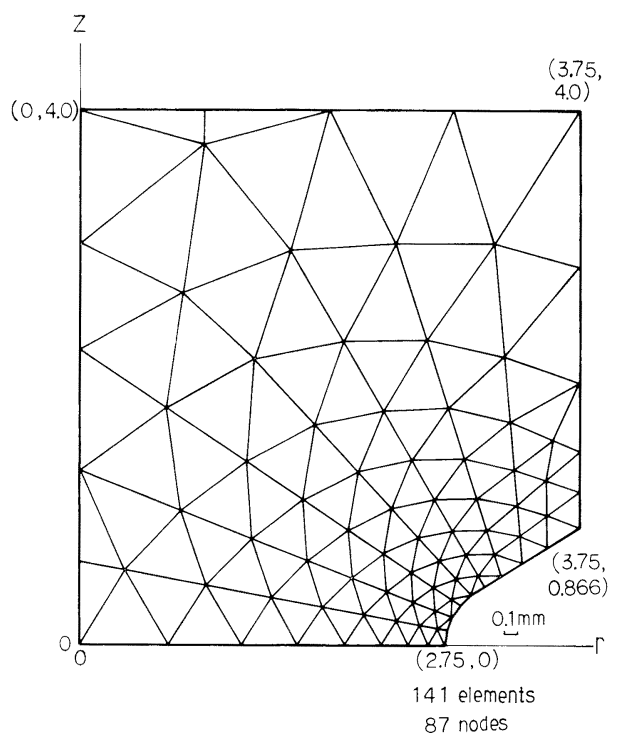

Fig. 1. Finite element model in this work. 


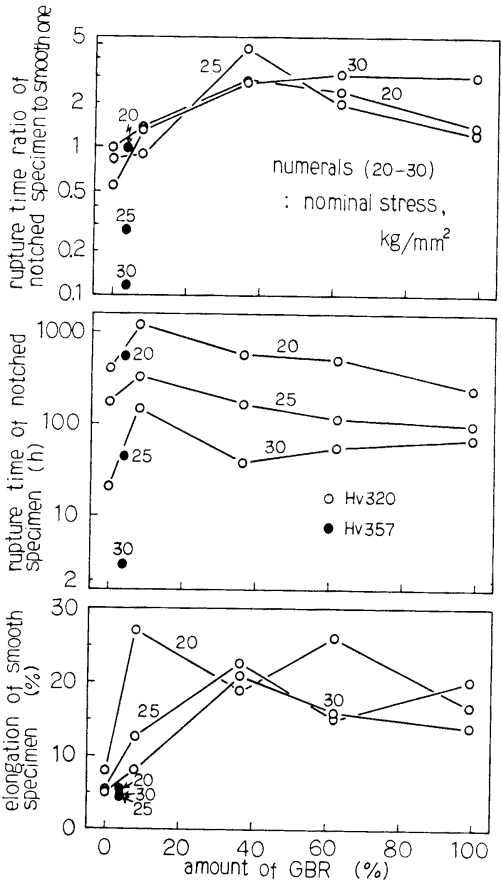

Fig. 2. Relationship between creep rupture properties at $700^{\circ} \mathrm{C}$ and amount of the grain boundary reaction.

をFig. 2 に示した．粒界反心显が $8 \%$ 以上の忉料は反 心量 $0 \%$ の材料や硬さの高い材料之闹じ程度か，それを 上回るクリープ破断強さを示し，反心量 $8 \%$ 付近で破断 時間は最も長くなる。一方，半滑材の破断伸びは反伈量 8\% 以上:の材料で大きくなるが，この上らな延性の增加 に刘応して反灾量 $8 \%$ 以上の材料では添淁切り欠き強化 となつている。たとえば，反灾量 $36 \%$ の材料では破断 伸びは約 18〜22\% と大体一定で，平滑材に対ずる切り 欠き材の破断時間此は $2.7 \sim 4.7$ である.こ机らに対し て，硬さの高い材料と反心最 $0 \%$ の材料では平滑材の破 断伸びが小さく，とくに前者では約 4.4 5.5\% であ る。これらの材料は公称心力が富くなるほど著しい切り 久き弱化を示吉傾向にあり，興味深い。また，試駼後の 組織と硬さの変化はほとんどなかつた。

このように粒界反応量や硬さの違いによつて切り欠き 材のクリープ破断強さは影臂されるが，これらの材料の らち典型的な切り欠き強化を示吉硬さ Hv 320，反心昆 36\% の材料を延性材，切り欠き弱化を示す硬さ Hv 357 , 反応量 $4 \%$ のものをぜい性材之呼び，以後これら二鋼 の実験結果抒よび有限要素法による計算結果について抒 もに述べる。

Fig. 3 に延性材とぜい性材の $600^{\circ} \sim 800^{\circ} \mathrm{C}$ に抢放

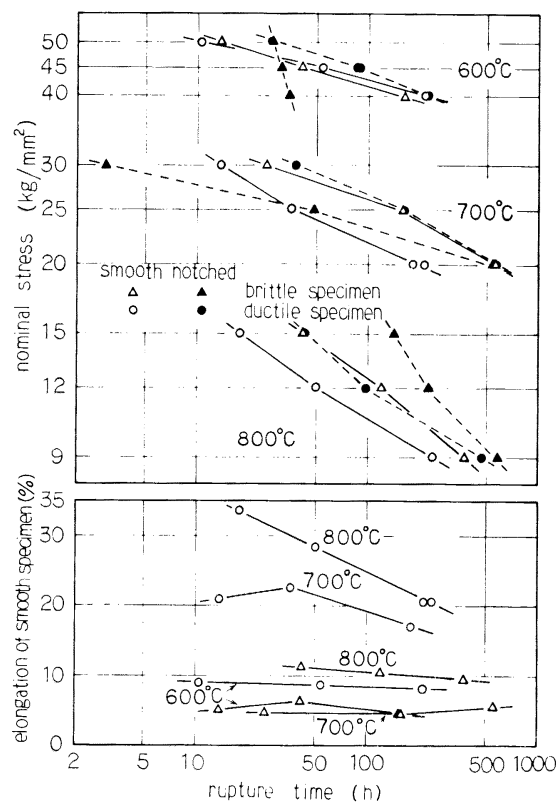

Fig. 3. Creep rupture properties of the ductile $(\mathrm{Hv}$ $320,36 \% \mathrm{GBR}$ ) and the brittle ( $\mathrm{Hv} 357,4$ $\%$ GBR) specimens.

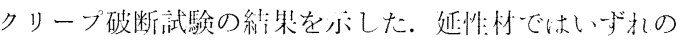

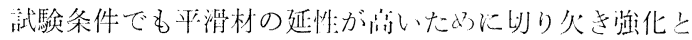
なり，平滑材の延性が低いぜい州材ではとくに $700^{\circ} \mathrm{C}$ に扔いて公称心力の增加之ともに鿓しい划り炎き弱化を

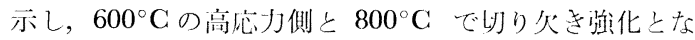

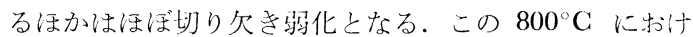
る切り欠き強化は明らか延性が监くなることに上る が，600 $\mathrm{C}$ では平滑材の延性が低いので问心側での切 り欠き強化を延性の大小のみでは説明できない。この点 については， $600^{\circ} \mathrm{C}$ の尚忘力側で可沙材之罢なり，切り

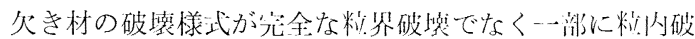
壊が起こるので，これにともなら局部的な延性:の增加が ぜい性材の切り欠き強化と圆係があると学えられる。

上述の延性材とぜい性材について $\dot{\varepsilon}_{\mathrm{cq} \mathrm{p}}=A \sigma_{\mathrm{eq}}^{\mathrm{n}}$ の $A$ 之 $n$ を平滑材のクリープ陚験の絬果から求めたとこう, $700^{\circ} \mathrm{C}$ では胼者は $A=1.11 \times 10^{-13}, n=7.31$ ，後著は $A=9.72 \times 10^{-15}, n=7.50$ であつた，以卜にに:述の：秏

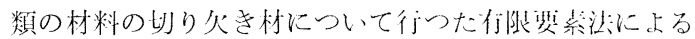

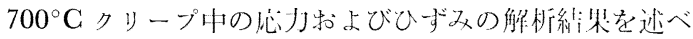
る.

\section{$4 \cdot 2$ 有限要素法による切欠材のクリープ解析}

$700^{\circ} \mathrm{C}$ で公称応力が $25 \mathrm{~kg} / \mathrm{mm}^{2}$ の埸介について, ク リープ変形による切り欠き底での軲力问心生 $\sigma_{z}$, 相当心 


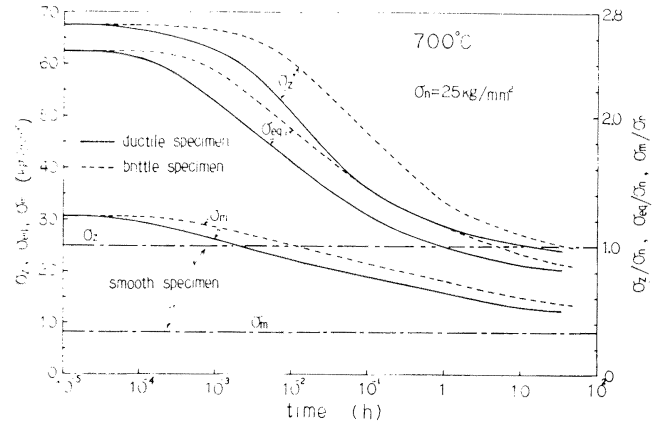

Fig. 4. Change in the axial stress $\sigma_{z}$, the equivalent stress $\sigma_{\mathrm{eq}}$ and the mean stress $\sigma_{\mathrm{m}}$ at notch root during creep at $700^{\circ} \mathrm{C}, 25 \mathrm{~kg} /$ $\mathrm{mm}^{2}$.

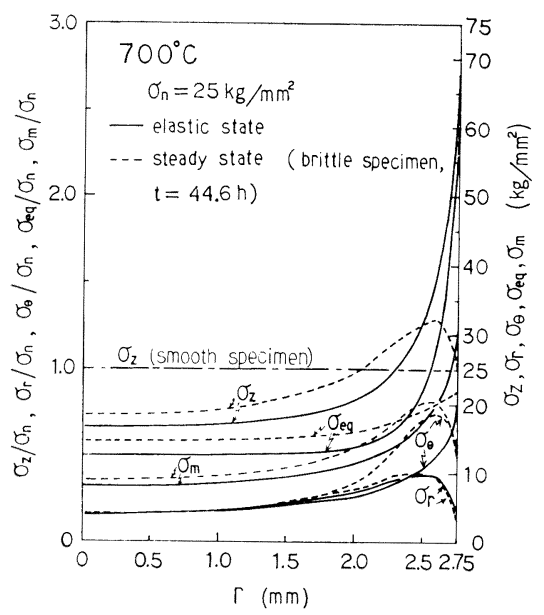

Fig. 5. Stress distribution in the minimum cross section at notch root during creep at 700 ${ }^{\circ} \mathrm{C}, 25 \mathrm{~kg} / \mathrm{mm}^{2}$.

力 $\sigma_{\mathrm{c} 1 \mathrm{1}}$, お小び均忠力 $\sigma_{\mathrm{m}}\left(=\left(\sigma_{\mathrm{r}}+\sigma_{\theta}+\sigma_{\mathrm{z}}\right) / 3, \sigma_{\mathrm{r}}\right.$ :

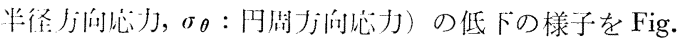
4 に心した。延性材のちがぜい性忉よりも $\sigma_{\mathrm{z}}, \sigma_{\mathrm{eq}}, \sigma_{\mathrm{m}}$ の低下が早期に起こり，また，画方の材料に拈いて $\sigma_{z}$, $\sigma_{\mathrm{eq}}$ の值はクリープ変形が進むと公称㤁力の健よりも小

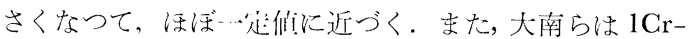
$1 \mathrm{No}-1 / 4 \mathrm{~V}$ 鋼のクリープ解析で，切り欠き強化となる場 余は切り欠き底の沟地力 $\sigma_{\mathrm{m}}$ は平滑材のそ扎に比べて 小さく，甽り火き弱化となるとさには逆になることを報 告している15)が，本研究では切り火き強化，切り欠き弱 化をホすす材料のいずれにおいても，切り欠き底での平均

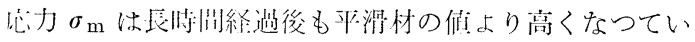
る.

Fig. 5 に临性状態とほぼ迄常状態における切り欠き底

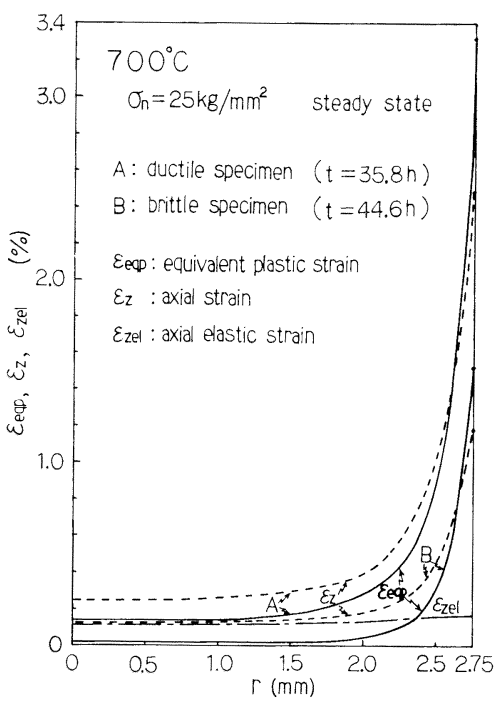

Fig. 6. Steady-state strain distribution in the minimum cross section at notch root during creep at $700^{\circ} \mathrm{C}, 25 \mathrm{~kg} / \mathrm{mm}^{2}$.

最小断面内の応力分布を示した．分常状態に近いと材料 の違いによる応力分布の差はほとんどないので，ぜい性 化材の切り欠き材で破断が起こる時点での計算值のみを 示した。 まず，弾性状態では $\sigma_{\mathrm{z}}$ は切り欠き底で聂大と なり，計算による応力集中係数 $K_{\mathrm{FEM}}=2.70$ で,切り欠 き係数 $K_{\mathrm{t}}=2.4$ よりも少し大きいま立た，軸方向応力 $\sigma_{Z}$, 接線方向㤁力 $\sigma_{\theta}$, 半径方向応力 $\sigma_{\mathrm{r}}$ などの分布に ついても従来の研究報告5) 6) と傾问は一致する.起常状態 では $\sigma_{z}, \sigma_{\theta}$ および $\sigma_{\mathrm{m}}$ は切り欠き底から少し内部に入 つたところに最大值が移つて扮り， $K_{\mathrm{FEM}}=1.29$ 程度に なる。亦た，弾性状態と比べると各忍力の平均化の起こ つていることが明らかである。

つぎに，公称灾力が $25 \mathrm{~kg} / \mathrm{mm}^{2}$ で，延性材について は平滑材の破断が，ぜい性材については切り欠き材の破 断が起る時点での，最小断面内の軸方向ひずみ $\varepsilon_{z}$ 之相 当塑性ひずみ $\varepsilon_{\mathrm{eqp}}$ の分布を Fig. 6 に示した. この状 態での軸方向弾性ひずみ $\varepsilon_{\mathrm{zel}}$ は材料にほぼ無関係であ る. $\varepsilon_{\mathrm{eqp}}$ と $\varepsilon_{\mathrm{z}}$ は切り欠さ底で最大となるが，内部で は非常に小さく，これは大路らの報告6) と傾问が同じで ある。また，延性材ではぜい性材よりも塑性変形星は大 きい，切り欠き強化を示す延性材では平滑材の破断時間

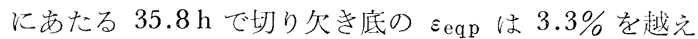
るが，まだき裂は生じない。しかし，ぜい性材では切り 欠き底の $\varepsilon_{\mathrm{eqp}}$ が $1.52 \%$ となる $44.6 \mathrm{~h}$ で切り欠き材 は破断して扣り，この值は同じ材料の平滑材の破断伸び よりも小さい. 


\section{3 材料の切欠き強化および切り欠き弱化におよぼす 諸因子の影響}

に述の切り欠き忚の切り欠き低に叔ける相当ひずみ $\varepsilon_{\mathrm{cq}}$ (相当望性ひげみ $\varepsilon_{\mathrm{eqp}}$ と相当弾性ひずみ $\varepsilon_{\mathrm{eqp}}$ の稩) の時間的变化をFig. 7 に示した。直線は走常クリーブ モデルによる平滑材の佔である。切り久き強化を示す延 性材では変形の初期にはクリープ速度掞よびクリーブ変 形量とも平滑材の值より大きいが，クリープ速度が時间 の経過とともに急速に減少するため，切り欠さ低の相当 ひずみ $\varepsilon_{\mathrm{eq}}$ は平滑材の值よりもかなり小さくなる。一 方，切り欠き弱化となるぜい性材でも切り欠き底のクリ 一プ速度は時間とともに減少するが，著しい切り欠き弱 化を示す $25 \mathrm{~kg} / \mathrm{mm}^{2}$ 以トの公称忘力では切り欠き底の 相当ひずみ $\varepsilon_{\mathrm{eq}}$ は平滑材の值よりも常に大きい。これ らのことは大南らの報告15) と傾问が一致する。さらに Fig. 8 をみると，ぜい性材では切り欠き材の破断時に お㤃る切り欠き底のクリープひずみ（相当塑性ひずみ $\left.\varepsilon_{\mathrm{eqp}}\right)$ は約 $1 . \mathrm{I} \sim 1.9 \%$ で，平滑材の破断伸びの約 4.4 〜 $5.5 \%$ に比べて小さく, 実験で求めた平滑材のき裂発 生時のクリープひずみ約 $2.2 \%$ (他力 $25 \mathrm{~kg} / \mathrm{mm}^{2}$ ) に 近い。また，分常クリープモデルによる平清材のクリー

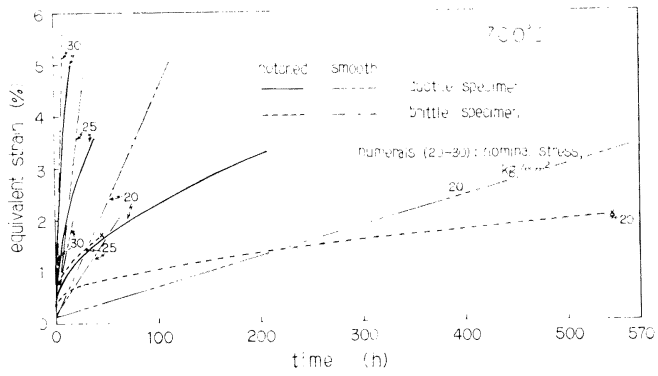

Fig. 7. Change in the equivalent strain at notch root in the ductile and the brittle specimens during creep at $700^{\circ} \mathrm{C}$.

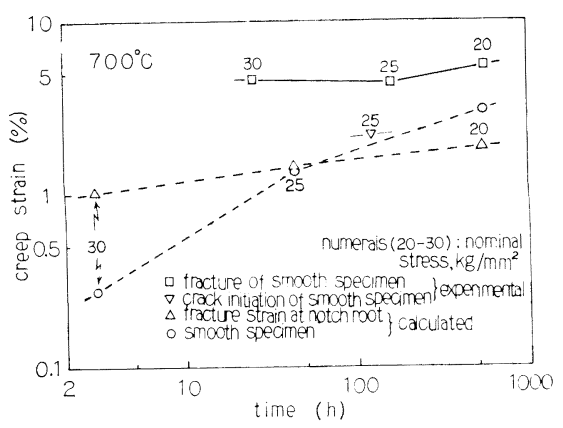

Fig. 8. Creep strains at notch root and of smooth specimen of the brittle steel at $700^{\circ} \mathrm{C}$.

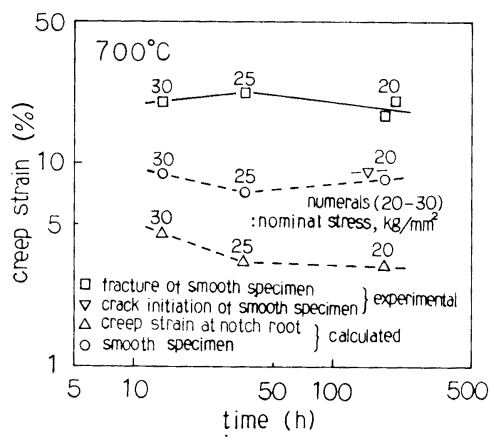

lig. 9. Greep strains at notch root and of smooth specimen of the ductile steel at $700^{\circ} \mathrm{C}$.

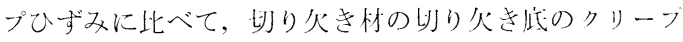
ひずみは公称心力が高くなると相刘的に大きくなる。こ

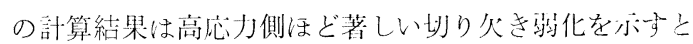
いう実験結果を説明するものである。‥J，Fig.9の迎 性材では平浡材の破断時に相当する特点での切り久さ材 の切り欠き底でのクリープひずみは 4.6〜3.0\% 程度 で，定常クリープモデルの值の約1/2〜1/3であり，Fig. $2 ， 3$ に2られる切り欠き强化に刘心与る。立た，中消 材のき裂発生時のクリーブひ-゙みは約 $9.2 \%$ (吣 20 $\left.\mathrm{kg} / \mathrm{mm}^{2}\right)$ でぜい性恻よりもかなり人きいが，こ机はす でに報告したよらに

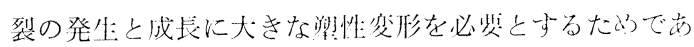
る.さらに，延性材でもFig. 4 に小したよらに切り久

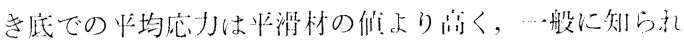

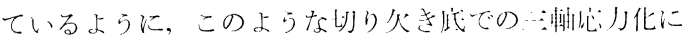

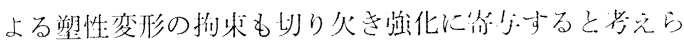
れる.

つぎに，ぜい性材の切り火き弱化について考多察する。 ぜい性材の破断直前の怡均分 $\sigma_{\mathrm{m}}$ は Fig. 5 のよ5に 切り欠き底表而から少し内部に入つたところで收高とな

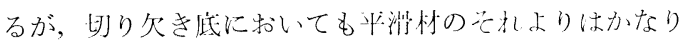

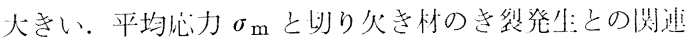

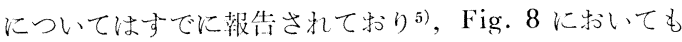

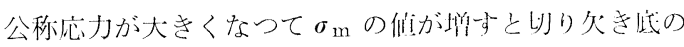
破断時のクリープひずみは少し小さくなる。しかし，本

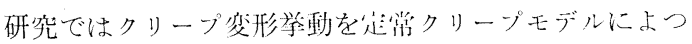
て近似して解析を行つている㸃を教柋すると，この程度 の変化はあまり大きなものではないといえる。したがつ て，ぜい性材では公称灿力が $20 \sim 30 \mathrm{~kg} / \mathrm{mm}^{2}$ では,

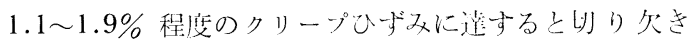

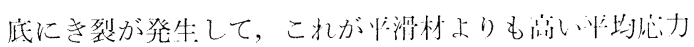
のもとで急速に伝播し破断に彷ると考兄られる。以に:の

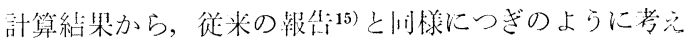



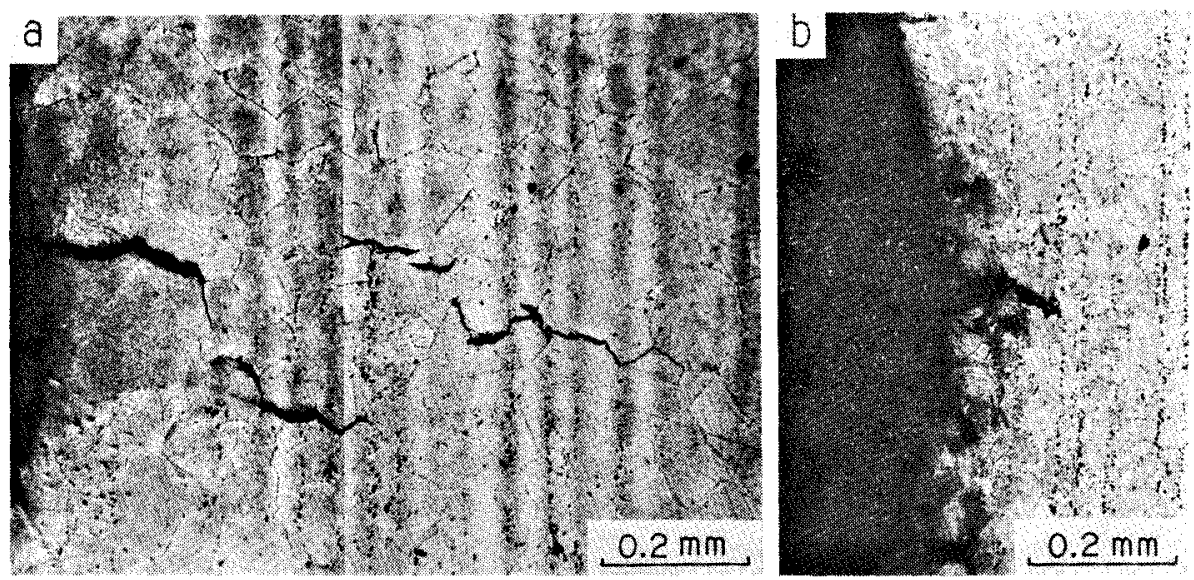

(a) Brittle specimen (Hv 357, 4\% GBR (b) Ductile specimen (Hv 320,36\% GBR)

Photo. 1. Grain boundary cracks at notch root occurred during creep at $700^{\circ} \mathrm{C}, 25 \mathrm{~kg} / \mathrm{mm}^{2}$

られる。ぜい性材の切り欠き材では公称浨力が高くなる 汪ど切り欠き底のクリープ変形が平滑材のとれよりも相 対的に著しく起こり，㴗滦一定のクリープひずみに達し たときき裂が生じて高い平均応力のもとで急速に伝播す

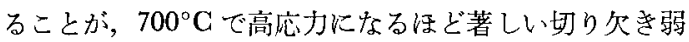
化を示すおるな原因である。これに対して，延性材では クリープ变形にともなつて切り欠き底に批ける応力集中 が急速に楥和され，切り欠き底での相当応力の低下が起 こつてその值が平滑材の引張応力よりる低くなるととも に，三軸応力化に上る塑性変形の拘束が起こつて平滑材 よりもクリープ変形が相対的に起こりにくくなり，き裂 発生が崌延するため切り欠き強化を示す。

\section{4 切り欠き材におけるクリープき裂の発生について}

上述のよらに従来の多くの報告と同じく本研究でも材 料の変形挙動衫よび延性の違いは切り欠さ材のクリープ 破断強さに大さな影響を执よぼすが，つぎにこの点につ いて組織観察の結果をもとに検討した. Photo. 1 は公称 応力 $25 \mathrm{~kg} / \mathrm{mm}_{2}$ でクリープ破断させた二重切り欠き材 の未破断部の切り欠底の光蹎写真である. Photo. 1 (a)のぜい性材では長い直線的な粒界き裂が，クリー プひずみが最大となる切り欠き底表面から生じるが， Photo. 1(b)の延性村では前報10)で述べたように粒界反 応ノジュールの界面にき裂が起こりやすく10)，切り欠き 底の広い範囲にわたつて多数の短いき裂が生じる。 た，破面を走查電顕で調べると延性材では dimple 破 面が，ぜい性材では粒界破面が観察された。大谷らが 切り欠き丸棒試験片に打けるクリープき裂発生位置と平 均応力 $\sigma_{\mathrm{m}}$ のピーク位置との間に対応があることを示唆 しているが，本研究ではぜい性材と延性材の両方に和い て定常状態での $\sigma_{\mathrm{m}}$ のピーク位置はき裂発生場所の切り
欠き底ではなく，少し内部に入つたところにあり，一 方, 相当応力 $\sigma_{\mathrm{eq}}$ は切り欠き底で最大となる。南ら は切り欠き材のき裂発生の要因として，切り欠き底での 相当応力の注かに艺こでの平均応力の大きさる考完てい るが，本研究では切り欠き底の平均応力の材料による差 は汪とんどなく，また，上述の解析結果からみて，延性 材とぜい性材の両方のき裂発生を支配するのは，切り欠 き底での相当応力とき裂発生までの材料の延性の大きさ であり，平均応力の影響㤌小さいと考えられる. 切り欠 き材のき裂伝播についての詳細な観察は行つていない が，平滑材と同じく切り欠き材でもき裂㤬材料の延性 の大小によらず，破断時間の約 80〜90\%の第亚期クリ 一プ中に生じるので，切り欠き材の破断寿命は柱は裂 発生までの時間によつてき委ると考党られる。硬さの高 いぜい性材ではわずかなタリープ変形によつて切り欠き 底にき裂が発生するが，粒界反応量 36\% の延性材では その発生に大きな塑性変形を必要とする。このようなき 裂発生までの延性の違いが切り欠き強化扣よび切り欠き 弱化に大きな影響をおよぽす。

\section{5. 結}

言

オーステナイト系の 21-4N 耐熱鋼を用い，切り欠を 材のクリープ破断強さにおよ湾す材料特性の影響につい て，有限要素法による切り欠き材のクリープ中の応力括 よびひずみの解析を行い検討した。 以下に得られた結果 を要約する。

(1) $700^{\circ} \mathrm{C}$ に扣いて切り欠き強化となる延性材 (Hv 320, 粒界反応量 36\% の材料) では，クリープ中 の切り欠底の相当応力, 軸力向応力拉よび平均応力の 低下は妇り欠き弱化を示すぜい性材 (Hv 357, 粒界反心 


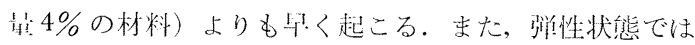

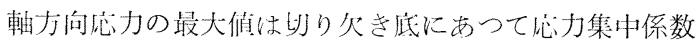
は2.70であるが，定常状態に近づくと材料や公称応力 によらず朝方向応力の最大值は内部一移り, 応力集中係 数はたと艺ば $25 \mathrm{~kg} / \mathrm{mm}^{2}$ の公称沁力では 1.29 程度に 低下ずる。定常状態では平均応力の最大值も内部一移る が，切り欠底でのその值は材料によらず平滑材の值よ り高い。

（2）切り欠き底の相当ひず文（相当塑性ひず文之相 当弾性ひずみの和）特よびクリープ速度は，クリープ変 形の初期を除けば延性材に执いては定常》リープモデル による平滑材の值より小さいが，ぜい性材で著しい切り 欠き弱化を示す高応力側では切り欠き底の相当ひずみは モデル化した平滑材の值よりつ称に大きい。また，ぜい 性材では高応力になる汪ど切り欠き底のクリープ変形が 足常クリープモデルの平滑材のそれよりも相対的に急速 に起こる。

（3）ぜい性材では公称応力が高い注ど切り欠き底の クリープ変形が平滑材に比べて急速に起こるため，700

${ }^{\circ} \mathrm{C}$ の切り欠き材のクリープ破断試験に执いて高応力ほ ぞ著しい切り欠き弱化を示すことが明らかとなつた。 た，本研究に扣いて子従来の報告之同様，つぎの上らに 考えられる。すなわち，延性材の切り火き強化はクリ一

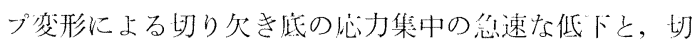
り欠き底の三軸応力化による塑性変形の拘東によつて， 平滑材よりも切り欠き材のクリープ変形が起こりにくく なるために牛じる。一お， ぜい性材では切り欠き底の応 力集中が十分低くならないらちにクリープ変形が進及,

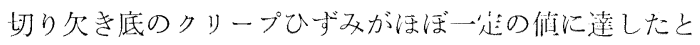
きに破壊が起こる.

（4）二重切り欠き材の破断後の未破断部切り欠き底 の光顕観察によると，ぜい性材では切り欠き底に長い粒 界き裂が，延性材では切り欠き底の広い範团に多数の微 小き裂が認められた。この組織観察とクリープ解析の両 方の結果から，ぜい性材，延性材のいずれでも切り欠き 材のき裂発生を支配するのは切り欠き底での相当応力之 き裂発生までの材料の延性の大きさであり, 従来の報告 とは異なり平均応力の影響は比較的小さいと考えられ

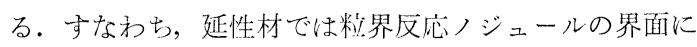
き裂が生じやずく，このようなき裂の発生までに大きな

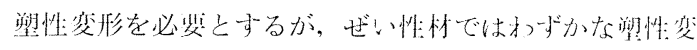
形でき裂が発生する。このよらなき裂の発生までの延性

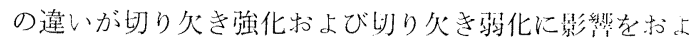
ぼす。亦た，平滑材と同じく切り欠き材でもき裂は材料 の延性の大小によらず，破断時阔の約 80〜90\%の第 III 期クリープ中に生じるので，划り久き忉の破断寿们は添 ぼき裂発生までの時間によつて沈まる。

終わりに，本研究を行らのにあたつて御助的いいただ いた東京都立大学工学部 宫川大海教授, 電子、汒筧機に

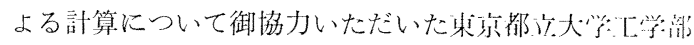
中村研究室の浅古豊助手打よび供試材を提供してトさつ た日鉦バルブ株式会社に深く感㴬致します。

\section{交献}

1) $H . R$. Voorhees, $J . W$. Freeman, and $J \cdot A$. Herzog: Trans. ASME, Ser. D, 84 (1962) 6. p. 207

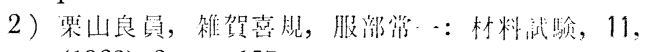
(1962) 3, p. 157

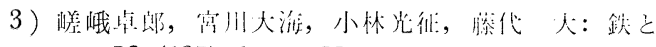
铜, 56 (197) 1, p. 55

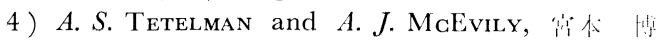

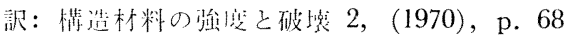
[培風飾］

5 ) 大谷降一, 仍箱 隆：材料, 20 (1971) 7, p.864

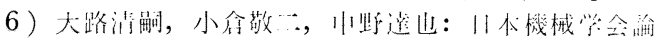
火集, 39 (1973) 3, p. 822

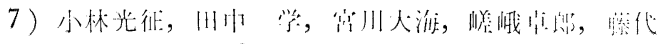
大：剑已錩，58 (1972) 14，p. 1984

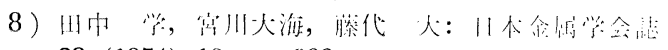
38 (1974) 10, p. 899

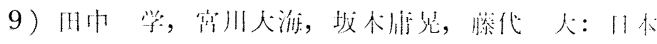
众属学会誌, 40 (1976) 5, p. 543

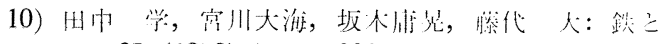
銓，65 (1979) 7, p. 939

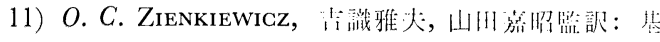

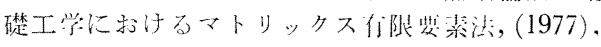
p. 80,369 [橖風館]

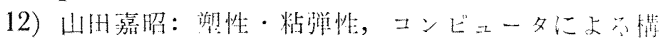
造工学構坐 II-2-A，(1975)，p. 175 [塔風飾]

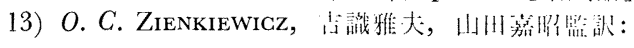

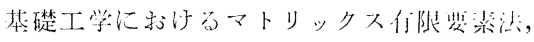
(1977), p. 512 [㙁風館]

14）村松䉆良：11本機械学:会䏯，68（1965）11, p. 111

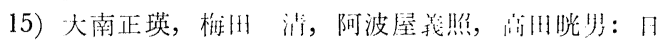
本機械学:会諭尖集，42（1976）2，p. 335 